\title{
Peramalan Produksi Beras di Provinsi Jawa Tengah
}

\author{
Muhammad Ridwan*1, Hari Purnomo ${ }^{2}$, Nancy Oktyajati ${ }^{3}$ \\ ${ }^{1,3}$ Program Studi Teknik Industri, Fakultas Teknik, Universitas Islam Batik Surakarta, Jl. \\ KH. Agus Salim No. 10, Surakarta, 57147, Indonesia \\ ${ }^{2}$ Program Studi Teknik industri, Fakultas Teknologi Industri, Universitas Islam Indonesia, \\ Jalan Kaliurang KM 14,5,Kabupaten Sleman, Daerah Istimewa Yogyakarta 55584, \\ Indonesia \\ e-mail: ${ }^{*}$ rimuh.ridwan26@gmail.com, ${ }^{2}$ haripurnomo@uii.ac.id, \\ ${ }^{3}$ oktyajati_nancy@gmail.com
}

(artikel diterima: 17-02-2021, artikel disetujui: 17-05-2021)

\begin{abstract}
Abstrak
Ketersediaan beras lokal perlu diprediksi untuk memenuhi kebutuhan pasokan beras di Indonesia. Jawa Tengah sebagai penghasil beras terbesar ketiga di Indonesia merupakan salah satu penopang kebutuhan beras nasional. Besarnya produksi pangan di Indonesia menjadi faktor penting dalam penentuan persediaan pangan yang tepat. Peramalan produksi beras di Jawa Tengah menjadi diperlukan untuk mengetahui kondisi pangan ke depan. Tujuan penelitian ini adalah untuk mengembangkan model peramalan produksi beras di provinsi Jawa Tengah dan mengetahui perkiraan produksi beras di Provinsi Jawa Tengah 5 tahun ke depan. Metode time series forecasting digunakan dalam penelitian ini. Data yang digunakan dalam penelitian ini adalah data hasil produksi beras dari tahun 1993 hingga tahun 2020. Dari hasil uji fungsi auto korelasi diketahui bahwa data produksi memiliki pola data tren. Metode yang digunakan dalam penelitian ini adalah metode double exponential smoothing dengan dua parameter (Holt's Methods). Model peramalan yang optimal didapatkan dengan bantuan software solver pada Microsoft Excel. Dengan menggunakan bantuan solver Microsoft Excel diperoleh nilai konstanta optimal $\alpha$ sebesar 0,767 dan $\beta$ sebesar 0,412 dengan nilai Mean Absolute Precentage Error sebesar 4,82\%. Hasil peramalan dari tahun 2021 hingga 2025 diketahui menurun setiap tahunnya. Rata-rata penurunan produksi beras dalam 5 tahun ke depan diperkirakan sebanyak $4,4 \%$ per tahunnya.
\end{abstract}

Kata kunci: beras, exponential smoothing, Jawa Tengah, peramalan

\begin{abstract}
The availability of local rice needs to be predicted to meet the demand for rice supply in Indonesia. Central Java, as the third largest rice producer in Indonesia, is one of the pillars of national rice demand. The amount of food production in Indonesia is an important factor in determining the right food supply. Forecasting rice production in Central Java is necessary to determine future food conditions. The purpose of this research is to develop a forecast model for rice production in Central Java province and to find out the estimated rice production in Central Java Province in the next 5 years. The time series forecasting method was used in this study. The data used in this study are data on rice production from 1993 to 2020. From the results of the Auto Correlation Function (ACF) test, it is known that the production data has a trend data pattern. The method used in this study is the double exponential smoothing method with two parameters (Holt's Methods). The optimal forecasting model is obtained with the help of solver software in Microsoft Excel. By using the help of the Microsoft Excel solver, the optimal constant value $\alpha$ is 0,767 and $\beta$ is 0,412 with a Mean Absolute Precentage Error value of 4,82\%. Forecasting results from 2021 to 2025 are known
\end{abstract}


to decline every year. The average decline in rice production in the next 5 years is estimated at $4,4 \%$ per year.

Keywords: rice, exponential smoothing, Central Java, forecasting

\section{PENDAHULUAN}

Sebagian besar masyarakat Indonesia mengkonsumsi beras sebagai bahan pokok strategis. Konsumsi beras di Indonesia dapat mempengaruhi stabilitas ekonomi (laju inflasi) dan stabilitas nasional (Nurjayanti, et al 2012). Karena ketergantungan terhadap konsumsi beras, maka ketersediaannya harus dapat terpenuhi (Nugroho and Sitepu, 2017). Hasil penelitian Bashir and Yuliana (2019) diketahui bahwa produksi beras dapat dipengaruhi oleh sumber daya manusia, tenaga kerja, upah, lahan basah, penduduk perkotaan, dan harga beras. Produksi beras sangat dinamis dan didukung oleh sumber daya lahan yang memadai, meskipun relatif terlokalisasi khususnya di wilayah Jawa-Bali. Selain itu, pengelolaan usaha tani juga menjadi aspek penting untuk meningkatkan produksi dan produktivitas (Panuju, et al 2013).

Salah satu daerah penyangga kebutuhan beras nasional adalah provinsi Jawa Tengah. Produksi di Jawa Tengah mengalami surplus sehingga dapat mendukung ketahanan pangan. Jawa Tengah merupakan penghasil produksi beras ketiga terbesar di Indonesia (Badan Pusat Statistik, 2019). Sedangkan teknologi tidak berpengaruh pada produksi beras. Oleh karena itu, peramalan produksi beras menjadi diperlukan untuk mengetahui kondisi pangan di Indonesia. Provinsi Jawa Tengah dipilih karena menjadi salah satu penyangga kebutuhan beras nasional. Tujuan penelitian ini adalah untuk mengembangkan model peramalan produksi beras di provinsi Jawa Tengah dan mengetahui perkiraan produksi beras di Provinsi Jawa Tengah 5 tahun ke depan.

Peramalan adalah dugaan satu atau beberapa kejadian masa depan (Montgomery et al., 2008). Peramalan merupakan suatu proses pengambilan keputusan untuk mendapatkan informasi di masa mendatang (Stevenson, 2002). Peramalan dapat dilakukan dengan menggunakan data historis yang kemudian diproyeksikan ke masa mendatang dengan model yang sistematis.

Dalam hubungan dengan horizon waktu peramalannya, dapat diklasifikasikan ke dalam 3 kelompok (Montgomery et al., 2008), yaitu : peramalan jangka pendek (short-term forecasting), meramalkan hanya dalam periode singkat (hari, minggu, atau bulan) ke depan; peramalan jangka menengah (medium-term forecasting), meramalkan satu atau dua tahun kedepan; dan peramalan jangka panjang (long-term forecasting), meramalkan beberapa tahun kedepan. Peramalan kuantitatif merupakan teknik peramalan yang menggunakan data historis dan sebuah model peramalan (Montgomery et al., 2008). Peramalan kualitatif ke dalam dua model, yaitu model peramalan kausal dan deret waktu. Model peramalan kausal adalah peramalan dengan mengembangkan suatu model sebab-akibat antara permintaan yang diramalkan dengan variabel-variabel lain yang dianggap berpengaruh. Sedangkan model peramalan deret waktu analisis pola hubungan antar variabel yang akan diperkirakan dengan variabel waktu.

Beberapa penelitian telah dilakukan terkait dengan peramalan produksi beras. Seperti, Kartikawati dan Asih (2017) melakukan analisis produksi dan konsumsi beras di Indonesia dengan menggunakan metode time series forecasting. Nugroho dan Sitepu (2017) melakukan peramalan produksi beras di Sumatera Utara dengan metode double exponential smoothing satu parameter (Brown's) dengan nilai $\alpha$ sebesar 0,4 dan MSE sebesar 2.303.552.227,83. Hasil penelitian Aziz dan Sopha (2016) tentang 
produksi padi di DIY menunjukkan bahwa metode Holts memiliki nilai MAPE, MAD, dan MSE terkecil dibandingkan metode lainnya. Nurjayanti et al. (2012) menggunakan metode ARIMA dalam penelitiannya tentang dinamika penawaran beras di kabupaten Sukoharjo tahun 2011 hingga tahun 2015. Peramalan menunjukkan bahwa penawaran beras cenderung menurun. Djafar et al., (2017) menggunakan metode Fuzzy Time Series untuk meramalkan produksi padi di provinsi Sulawesi Tenggara. Hasil produksi padi tahun 2015 diperkirakan sebesar 657.768,25191 ton dan MAPE dari peramalan sebesar 5,51\%. Peramalan produksi beras untuk provinsi Jawa Tengah dengan metode time series belum pernah dilakukan. Oleh karena itu, artikel ini akan memaparkan model peramalan produksi beras di provinsi Jawa Tengah dan mengetahui perkiraan produksi beras di Provinsi Jawa Tengah 5 tahun ke depan.

\section{METODE PENELITIAN}

Data yang diperlukan dalam penelitian ini adalah data produksi beras di Provinsi Jawa Tengah. Data diperoleh dari Badan Pusat Statistik Provinsi Jawa Tengah. Data berupa data sekunder dari tahun 1993 hingga tahun 2020.

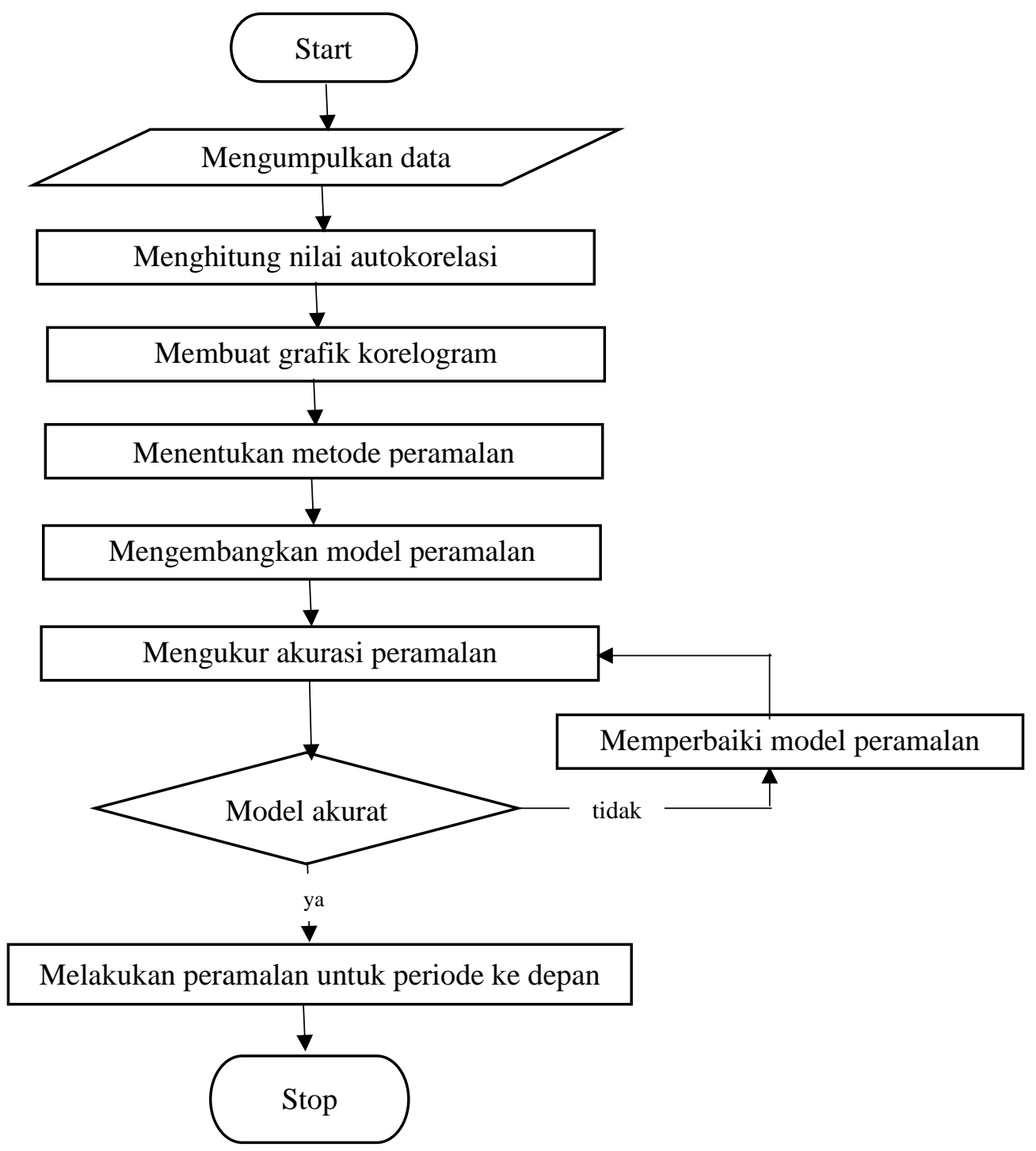

Gambar 1 Flowchart penelitian 
Langkah yang digunakan dalam penelitian ini adalah uji auto korelasi untuk mengetahui pola data dan metode peramalan yang akan digunakan, pembuatan model peramalan berdasarkan hasil uji autokorelasi, dan pengukuran kesalahan peramalan. Gambar 1 menggambarkan alur pengolahan data pada penelitian ini.

\subsection{Menghitung Nilai Auto Korelasi}

Autokorelasi adalah hubungan data time series antar selang waktu (lag). Digunakan untuk mengetahui kestasioneran data dan ada tidaknya seasonalitas pada data.

Persamaan matematis dari uji autokorelasi ditunjukkan pada persamaan (1):

$$
r_{k}=\frac{\sum_{t=k+1}^{n}\left(Y_{t}-\dot{Y}\right)\left(Y_{t-k}-\dot{Y}\right)}{\sum_{t=1}^{n}\left(Y_{t}-\dot{Y}\right)^{2}}
$$

dimana

$\mathrm{r}_{\mathrm{k}} \quad$ : nilai autokorelasi untuk lag $\mathrm{k}$

$\mathrm{Y}_{\mathrm{t}} \quad$ : nilai pada periode $\mathrm{t}$

$\mathrm{Y}_{\mathrm{t}-\mathrm{k}}$ : nilai pada periode $\mathrm{t}-\mathrm{k}$

$\hat{Y} \quad$ : nilai rata rata data

Kemudian dibuat grafik fungsi autokorelasi untuk mengetahui pola data penelitian. Pola data dikatakan random jika nilai autokorelasi $\mathrm{Y}_{\mathrm{t}}$ dan $\mathrm{Y}_{\mathrm{t}-\mathrm{k}}$ untuk setiap jeda waktu $\mathrm{k}$ adalah mendekati 0 .

\subsection{Analisis Pola Data}

Jika suatu rangkaian memiliki tren, pengamatan berurutan sangat berkorelasi, dan koefisien autokorelasi biasanya berbeda secara signifikan dari nol untuk beberapa jeda waktu pertama dan kemudian secara bertahap turun ke nol seiring bertambahnya jumlah kelambatan. Koefisien autokorelasi untuk jeda waktu 1 seringkali sangat besar (mendekati 1). Koefisien autokorelasi untuk jeda waktu 2 juga akan besar. Namun, tidak akan sebesar jeda waktu 1. Jika rangkaian memiliki pola musiman, koefisien autokorelasi yang signifikan akan terjadi pada jeda waktu musiman atau kelipatan dari jeda musim. Jeda musiman adalah 4 untuk data triwulanan dan 12 untuk data bulanan. (Hanke dan Wichern, 2014).

\subsection{Pemilihan Metode Peramalan}

Setelah pola data peramalan diketahui, kemudian dipilih metode peramalan yang akan digunakan. Pemilihan metode merujuk pada Tabel 1.

Tabel 1 Pemilihan Metode Peramalan

\begin{tabular}{lllc}
\hline \multicolumn{1}{c}{ Metode } & \multicolumn{1}{c}{ Pola Data } & Tipe Model & Data Minimal \\
\hline Naïve & Stationer, Trend, Seasonal & Time Series & 1 \\
Moving Average & Stationer & Time Series & $4-20$ \\
Exponential Smoothing & Stationer & Time Series & 2 \\
Double Exponential Smoothing (Holts) & Trend & Time Series & 3 \\
Triple Exponential Smoothing & Seasonal & Time Series & 2 x season \\
(Winters) & Semua Pola & Time Series & 24 \\
ARIMA & & & \\
\hline Sumber: (Hanke dan Wichern 2014) & & & \\
\hline
\end{tabular}




\subsection{Metode Peramalan}

Metode peramalan yang digunakan dalam penelitian ini adalah metode pemulusan (smoothing) deret waktu. Metode pemulusan menggunakan 2 metode, yaitu metode moving average dan metode exponential smoothing.

a. Metode moving average

Metode moving average merupakan metode peramalan dengan mencari nilai ratarata sebagian data yang dimiliki untuk dijadikan nilai peramalan yang akan datang (Subagyo, 2008). Moving average ber-orde 1 (MA1) disebut dengan metode naive (Hanke dan Wichern 2014). Persamaan matematis dari moving average ditunjukkan pada persamaan (2).

$Y_{t+1}=\frac{\mathrm{Y}_{\mathrm{t}}+\mathrm{Y}_{\mathrm{t}-1}+\ldots+\mathrm{Y}_{\mathrm{t}-(\mathrm{k}+1)}}{\mathrm{k}}$

dimana:

$\mathrm{Y}_{\mathrm{t}+1} \quad$ : hasil peramalan periode selanjutnya

$\mathrm{Y}_{\mathrm{t}} \quad$ : data penjualan periode $\mathrm{t}$

$\mathrm{k} \quad$ : jumlah data yang digunakan

b. Metode exponential smoothing

Metode exponential smoothing merupakan metode yang digunakan untuk penghalusan pola level, trend, dan seasonal tergantung tingkat exponensial yang digunakan (Hanke dan Wichern 2014). Persamaan matematis dari metode exponential smoothing ditampilkan pada persamaan (3):

$$
\widehat{Y}_{t+1}=\alpha Y_{t}+(1-\alpha) \hat{Y}_{t}
$$

dimana:

$\hat{\mathrm{Y}}_{\mathrm{t}+1} \quad$ : nilai peramalan periode selanjutnya

$\mathrm{Y}_{\mathrm{t}} \quad$ : nilai aktual periode $\mathrm{t}$

$\hat{\mathrm{Y}}_{\mathrm{t}} \quad$ : nilai peramalan periode $\mathrm{t}$

$\alpha \quad$ : konstanta atau bobot level dimana $0<\alpha<1$

c. Metode double exponential smoothing

Double exponential smoothing atau Holt's method merupakan metode single exponential smoothing dengan menambahkan unsur trend pada bobot perhitungan, sehingga pada double exponential smoothing, kita memberikan dua jenis bobot pada perhitungan yaitu level $(\alpha)$ dan trend $(\beta)$ (Hanke dan Wichern 2014). Persamaan matematis dari metode ini ditampilkan pada Persamaan (4) sampai dengan Persamaan (7).

$$
\begin{aligned}
& \hat{Y}_{t+1}=L_{t}+T_{t} \\
& L_{t}=\alpha Y_{t}+(1-\alpha)\left(L_{t-1}-T_{t-1}\right) \\
& T_{t}=\beta\left(L_{t}-L_{t-1}\right)+(1-\beta) T_{t-1}
\end{aligned}
$$

dimana:

$\hat{\mathrm{Y}}_{\mathrm{t}+1} \quad$ : nilai peramalan untuk periode berikutnya 


$\begin{array}{ll}\mathrm{L}_{\mathrm{t}} & : \text { nilai smoothed level pada periode } \mathrm{t} \\ \alpha & : \text { konstanta atau bobot level dimana } 0<\alpha<1 \\ \mathrm{Y}_{\mathrm{t}} & : \text { nilai data aktual periode } \mathrm{t} \\ \mathrm{L}_{\mathrm{t}-1} & : \text { nilai smoothed peramalan pada periode sebelumnya } \\ \mathrm{Tt} & : \text { nilai trend peramalan periode } \mathrm{t} \\ \beta & : \text { konstanta atau bobot trend dimana } 0<\beta<1 \\ \mathrm{~T}_{\mathrm{t}-1} & : \text { nilai trend peramalan pada periode sebelunya }\end{array}$

Sedangkan untuk peramalan beberapa tahun ke depan, menggunakan rumus Persamaan (7):

$$
\hat{Y}_{t+h}=L_{t}+(h) T_{t}
$$

dimana:

$\hat{Y}_{\mathrm{t}+\mathrm{h}} \quad$ : nilai peramalan untuk $\mathrm{h}$ periode waktu ke depan

$\mathrm{L}_{\mathrm{t}} \quad$ : nilai smoothed level pada periode $\mathrm{t}$

$\mathrm{Tt} \quad$ : nilai trend peramalan periode $\mathrm{t}$

h : periode waktu

\subsection{Pengukuran Kesalahan Peramalan}

Untuk mengetahui metode peramalan yang baik, kita perlu mengetahui tingkat kesalahan dari metode yang digunakan. Pengukuran tingkat kesalahan diukur dari selisih antara nilai aktual dan nilai peramalannya. Perbedaan antara nilai aktual dan nilai peramalan disebut dengan residual (Hanke dan Wichern 2014). Salah satu yang sering digunakan adalah mean absolute percentage error (MAPE). MAPE adalah nilai rata-rata presentase selisih absolut antara hasil perhitungan peramalan dengan hasil aktual yang diterima. MAPE dapat dihitung dengan menggunakan Persamaan (8).

$$
\mathrm{MAPE}=\frac{1}{n} \sum_{t=1}^{n} \frac{\left|Y_{t}-\hat{\mathrm{Y}}_{t}\right|}{Y_{t}} \times 100 \%
$$

dimana:

Yt $\quad$ : nilai aktual pada periode $\mathrm{t}$

$\hat{\mathrm{Y}} \mathrm{t} \quad$ : nilai peramalan pada periode $\mathrm{t}$

n : jumlah data

\section{HASIL DAN PEMBAHASAN}

Data diperoleh dari Badan Pusat Statistik provinsi Jawa Tengah dari tahun 1993 hingga tahun 2020. Adapun data hasil permintaan dapat dilihat pada Tabel 2.

Tabel 2 Produksi Padi Provinsi Jawa Tengah

\begin{tabular}{rrc}
\hline Periode & Tahun & Produksi \\
\hline 1 & 1993 & 8.174 .897 \\
2 & 1994 & 7.722 .611 \\
3 & 1995 & 8.198 .084 \\
4 & 1996 & 8.359 .105 \\
5 & 1997 & 8.328 .756
\end{tabular}




\begin{tabular}{rcr}
\hline Periode & Tahun & \multicolumn{1}{c}{ Produksi } \\
\hline 6 & 1998 & 8.594 .043 \\
7 & 1999 & 8.345 .854 \\
8 & 2000 & 8.475 .412 \\
9 & 2001 & 8.289 .927 \\
10 & 2002 & 8.503 .523 \\
11 & 2003 & 8.123 .839 \\
12 & 2004 & 8.512 .555 \\
13 & 2005 & 8.424 .096 \\
14 & 2006 & 8.729 .291 \\
15 & 2007 & 8.616 .855 \\
16 & 2008 & 9.136 .405 \\
17 & 2009 & 9.600 .415 \\
18 & 2010 & 10.110 .830 \\
19 & 2011 & 9.391 .959 \\
20 & 2012 & 10.232 .934 \\
21 & 2013 & 10.344 .816 \\
22 & 2014 & 9.648 .104 \\
23 & 2015 & 11.301 .422 \\
24 & 2016 & 11.473 .261 \\
25 & 2017 & 11.395 .395 \\
26 & 2018 & 10.499 .588 \\
27 & 2019 & 9.655 .654 \\
28 & 2020 & 9.586 .911 \\
\hline \multicolumn{3}{l}{ Sumber: (BPS 2020$)$}
\end{tabular}

\subsection{Uji Auto Korelasi}

Nilai autokorelasi untuk $\mathrm{k}=1$ adalah sebaai berikut:

$$
r_{1}=\frac{\sum_{t=2}^{28}\left(Y_{t}-\hat{Y}\right)\left(Y_{t-k}-\hat{Y}\right)}{\sum_{t=1}^{28}\left(Y_{t}-\hat{Y}\right)^{2}}
$$

$r_{1}$

$$
\begin{aligned}
= & \frac{(8.174 .897-9.206 .305)(8.174 .897-9.206 .305)+\cdots+(9.655 .654-9.206 .305)(9.586 .911-9.206 .305)}{(8.174 .897-9.206 .305)(8.174 .897-9.206 .305)+\cdots+(9.586 .911-9.206 .305)(9.586 .911-9.206 .305)} \\
& =\frac{962.883 .941 .146,46}{1.124 .669 .329 .561,85} \\
& =0,856148
\end{aligned}
$$

Hasil perhitungan nilai autokorelasi untuk keseluruhan data ditampilkan pada Tabel 3.

Tabel 3 Hasil Perhitungan Nilai Auto Korelasi

\begin{tabular}{cc}
\hline $\mathrm{k}$ & $\mathrm{r}_{\mathrm{k}}$ \\
\hline 1 & 0,856148 \\
2 & 0,733828 \\
3 & 0,613785 \\
4 & 0,483423 \\
5 & 0,388944 \\
6 & 0,297736 \\
7 & 0,209665
\end{tabular}




\begin{tabular}{cc}
\hline $\mathrm{k}$ & $\mathrm{r}_{\mathrm{k}}$ \\
\hline 8 & 0,104974 \\
9 & $-0,01471$ \\
10 & $-0,09881$ \\
11 & $-0,17057$ \\
12 & $-0,23679$ \\
13 & $-0,28008$ \\
14 & $-0,31308$ \\
15 & $-0,34031$ \\
16 & $-0,35566$ \\
17 & $-0,32841$ \\
18 & $-0,31665$ \\
19 & $-0,32035$ \\
20 & $-0,29343$ \\
21 & $-0,29983$ \\
22 & $-0,30023$ \\
23 & $-0,24149$ \\
24 & $-0,15726$ \\
25 & $-0,07572$ \\
26 & $-0,03265$ \\
27 & $-0,01247$ \\
\hline
\end{tabular}

Hasil dari perhitungan nilai auto korelasi selanjutnya diubah menjadi grafik untuk mengetahui fungsi auto korelasinya (Gambar 2). Dari Gambar 2 diketahui bahwa nilai autokorelasi pada lag - lag awal tinggi dan kemudian semakin menurun secara bertahap. Data yang memiliki nilai fungsi autokorelasi seperti gambar di atas memiliki pola data tidak stasioner dan memiliki tren. Maka dapat disimpulkan bahwa data produksi padi di Jawa Tengah memiliki pola data tren. Oleh karena itu dipilih metode double exponential smoothing untuk melakukan peramalan ke depan.

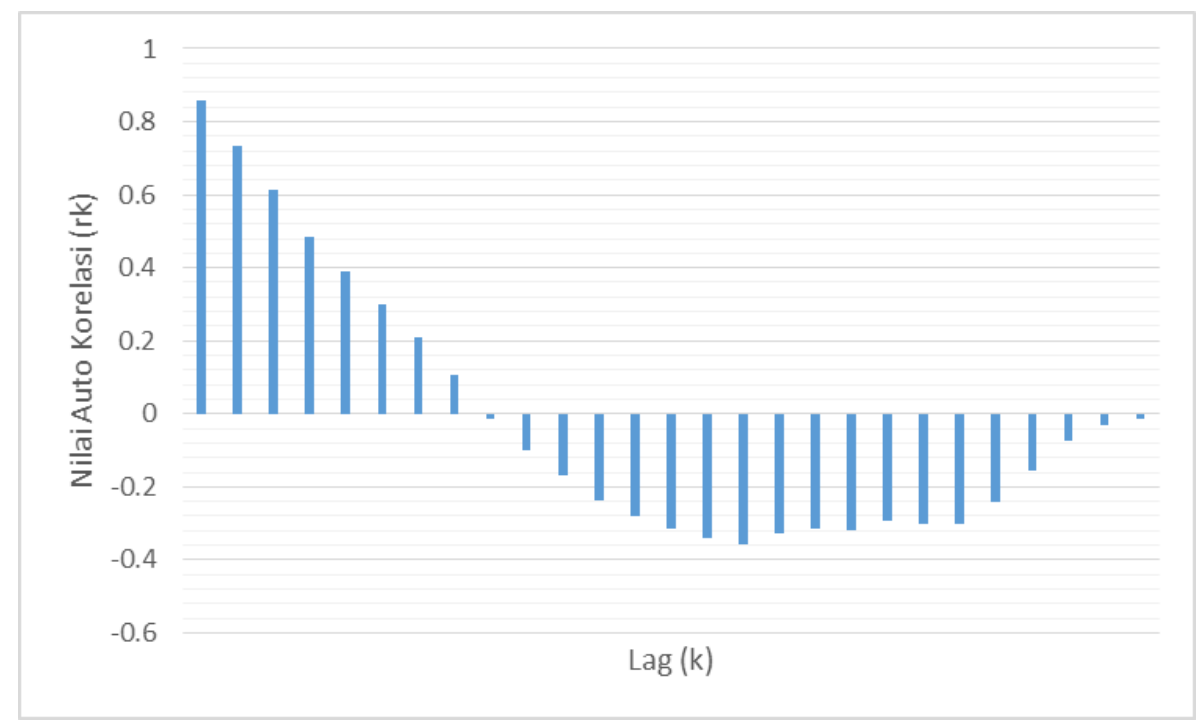

Gambar 2 Fungsi autokorelasi data 


\subsection{Pembuatan Model Peramalan}

Dalam pembuatan model peramalan pertama, ditentukan nilai koefisien $\alpha=0,5$ dan $\beta=0,5$. Nilai 0,5 dipilih untuk masing-masing koefisien karena mewakili nilai rata-rata. Pada metode doule exponential smoothing terdapat nilai inisial atau nilai awal. Nilai inisial tersebut antara lain:

$$
\begin{aligned}
& \mathrm{L}_{2}=\mathrm{Y}_{2}=7.722 .611 \\
& \mathrm{~T}_{2}=\mathrm{Y}_{2}-\mathrm{Y}_{1} \\
& \mathrm{~T}_{2}=7.722 .611-8.174 .897=-452.286 \\
& \hat{\mathrm{Y}}_{3}=L_{2}+T_{2} \\
& \hat{\mathrm{Y}}_{3}=7.722 .611+(-452.286)=7.270 .325
\end{aligned}
$$

Sedangkan perhitungan nilai peramalan dapat adalah sebagai berikut:

$$
\begin{aligned}
& L_{3}=0,5 \times Y_{3}+(1-0,5)\left(L_{2}+T_{2}\right) \\
& L_{3}=0,5 \times 8.198 .804+(1-0,5)(7.722 .611+(-452.286))=7.734 .205 \\
& T_{3}=0,5\left(L_{3}-L_{2}\right)+(1-0,5) T_{2} \\
& T_{3}=0,5(7.496 .468-7.722 .611)+(1-0,5)(-452.286)=-220.346 \\
& \hat{Y}_{4}=L_{3}+T_{3} \\
& \hat{Y}_{4}=7.734 .205+(-220.346)=7.513 .858
\end{aligned}
$$

Hasil peramalan untuk nilai $\alpha=0,5$ dan $\beta=0,5$ dapat dilihat pada Tabel 4 .

Tabel 4 Hasil Peramalan $\alpha=0,5$ dan $\beta=0,5$

\begin{tabular}{rcrrr}
\hline $\mathrm{t}$ & \multicolumn{1}{c}{$\mathrm{Y}_{\mathrm{t}}$} & \multicolumn{1}{c}{$\mathrm{L}_{\mathrm{t}}$} & \multicolumn{1}{c}{$\mathrm{T}_{\mathrm{t}}$} & $\hat{\mathrm{Y}}_{\mathrm{t}+1}$ \\
\hline 1 & 8.174 .897 & & & \\
2 & 7.722 .611 & 7.722 .611 & -452.286 & \\
3 & 8.198 .084 & 7.734 .205 & -220.346 & 7.270 .325 \\
4 & 8.359 .105 & 7.936 .482 & -9.035 & 7.513 .858 \\
5 & 8.328 .756 & 8.128 .102 & 91.293 & 7.927 .447 \\
6 & 8.594 .043 & 8.406 .719 & 184.955 & 8.219 .394 \\
7 & 8.345 .854 & 8.468 .764 & 123.500 & 8.591 .673 \\
8 & 8.475 .412 & 8.533 .838 & 94.287 & 8.592 .264 \\
9 & 8.289 .927 & 8.459 .026 & 9.738 & 8.628 .125 \\
10 & 8.503 .523 & 8.486 .143 & 18.427 & 8.468 .764 \\
11 & 8.123 .839 & 8.314 .205 & -76.755 & 8.504 .571 \\
12 & 8.512 .555 & 8.375 .002 & -7.979 & 8.237 .449 \\
13 & 8.424 .096 & 8.395 .560 & 6.289 & 8.367 .023 \\
14 & 8.729 .291 & 8.565 .570 & 88.150 & 8.401 .849 \\
15 & 8.616 .855 & 8.635 .287 & 78.934 & 8.653 .720 \\
16 & 9.136 .405 & 8.925 .313 & 184.480 & 8.714 .221 \\
17 & 9.600 .415 & 9.355 .104 & 307.135 & 9.109 .793
\end{tabular}




\begin{tabular}{rrrrr}
\hline $\mathrm{t}$ & \multicolumn{1}{c}{$\mathrm{Y}_{\mathrm{t}}$} & \multicolumn{1}{c}{$\mathrm{L}_{\mathrm{t}}$} & \multicolumn{1}{c}{$\mathrm{T}_{\mathrm{t}}$} & \multicolumn{1}{c}{$\hat{\mathrm{Y}}_{\mathrm{t}+1}$} \\
\hline 18 & 10.110 .830 & 9.886 .534 & 419.283 & 9.662 .239 \\
19 & 9.391 .959 & 9.848 .888 & 190.818 & 10.305 .817 \\
20 & 10.232 .934 & 10.136 .320 & 239.125 & 10.039 .707 \\
21 & 10.344 .816 & 10.360 .131 & 231.468 & 10.375 .446 \\
22 & 9.648 .104 & 10.119 .851 & -4.406 & 10.591 .599 \\
23 & 11.301 .422 & 10.708 .434 & 292.088 & 10.115 .445 \\
24 & 11.473 .261 & 11.236 .892 & 410.273 & 11.000 .522 \\
25 & 11.395 .395 & 11.521 .280 & 347.331 & 11.647 .165 \\
26 & 10.499 .588 & 11.184 .099 & 5.075 & 11.868 .610 \\
27 & 9.655 .654 & 10.422 .414 & -378.305 & 11.189 .174 \\
28 & 9.586 .911 & 9.815 .510 & -492.605 & 10.044 .109 \\
\hline
\end{tabular}

\subsection{Pengukuran Kesalahan Peramalan}

Kesalahan peramalan diukur dengan menggunakan metode MAPE. MAPE adalah nilai rata-rata presentase selisih absolut antara hasil perhitungan peramalan dengan hasil aktual yang diterima. MAPE dipilih karena nilai data yang diramal besar. Pengukuran dengan MAPE mempermudah dalam membaca kesalahan peramalan. Hasil perhitungan MAPE ditampilkan pada Tabel 5.

Tabel 5 Perhitungan MAPE

\begin{tabular}{rrrr}
$\mathrm{t}$ & \multicolumn{1}{c}{$\mathrm{Y}_{\mathrm{t}}$} & \multicolumn{1}{c}{$\hat{\mathrm{Y}}_{\mathrm{t}}$} & $\mathrm{Y}_{\mathrm{t}}-\hat{\mathrm{Y}}_{\mathrm{t}} / / \mathrm{Y}_{\mathrm{t}} \times 100$ \\
\hline 1 & 8.174 .897 & & \\
2 & 7.722 .611 & & \\
3 & 8.198 .084 & 7.270 .325 & 11,317 \\
4 & 8.359 .105 & 7.513 .858 & 10,112 \\
5 & 8.328 .756 & 7.927 .447 & 4,818 \\
6 & 8.594 .043 & 8.219 .394 & 4,359 \\
7 & 8.345 .854 & 8.591 .673 & 2,945 \\
8 & 8.475 .412 & 8.592 .264 & 1,379 \\
9 & 8.289 .927 & 8.628 .125 & 4,08 \\
10 & 8.503 .523 & 8.468 .764 & 0,409 \\
11 & 8.123 .839 & 8.504 .571 & 4,687 \\
12 & 8.512 .555 & 8.237 .449 & 3,232 \\
13 & 8.424 .096 & 8.367 .023 & 0,677 \\
14 & 8.729 .291 & 8.401 .849 & 3,751 \\
15 & 8.616 .855 & 8.653 .720 & 0,428 \\
16 & 9.136 .405 & 8.714 .221 & 4,621 \\
17 & 9.600 .415 & 9.109 .793 & 5,11 \\
18 & 10.110 .830 & 9.662 .239 & 4,437 \\
19 & 9.391 .959 & 10.305 .817 & 9,73 \\
20 & 10.232 .934 & 10.039 .707 & 1,888 \\
21 & 10.344 .816 & 10.375 .446 & 0,296 \\
22 & 9.648 .104 & 10.591 .599 & 9,779 \\
\hline
\end{tabular}




\begin{tabular}{rrrr}
\hline $\mathrm{t}$ & \multicolumn{1}{c}{$\mathrm{Y}_{\mathrm{t}}$} & \multicolumn{1}{c}{$\hat{\mathrm{Y}}_{\mathrm{t}}$} & $\mathrm{Y}_{\mathrm{t}}-\hat{\mathrm{Y}}_{\mathrm{t}} / \mathrm{Y}_{\mathrm{t}} \mathrm{x} \mathrm{100}$ \\
\hline 23 & 11.301 .422 & 10.115 .445 & 10,494 \\
24 & 11.473 .261 & 11.000 .522 & 4,12 \\
25 & 11.395 .395 & 11.647 .165 & 2,209 \\
26 & 10.499 .588 & 11.868 .610 & 13,039 \\
27 & 9.655 .654 & 11.189 .174 & 15,882 \\
28 & 9586911 & 10044109 & 4,769 \\
& & MAPE & 5,33 \\
\hline
\end{tabular}

\subsection{Optimasi Peramalan}

Optimasi peramalan dilakukan dengan cara merubah nilai konstanta $\alpha$ dan $\beta$. Untuk merubah nilai $\alpha$ dan $\beta$ maka digunakan bantuan dari Solver. Parameter yang dimasukkan ke dalam solver antara lain:

- Target : meminimalkan nilai MAPE

- Data yang akan diubah :nilai koefisien $\alpha$ dan $\gamma$

- Konstrain : $0 \leq \alpha \leq 1$

$$
0 \leq \beta \leq 1
$$

Hasil dari solver analysis pada Microsoft Excel diperoleh bahwa nilai $\alpha$ optimal adalah 0,767 dan nilai $\beta 0,412$. Hasil peramalan untuk nilai $\alpha=0,5$ dan $\beta=0,5$ dapat dilihat pada Tabel 6 .

Tabel 6 Hasil Peramalan Optimal dan Nilai MAPE

\begin{tabular}{rrrrrr}
$\mathrm{T}$ & \multicolumn{1}{c}{$\mathrm{Y}_{\mathrm{t}}$} & \multicolumn{1}{c}{$\mathrm{L}_{\mathrm{t}}$} & \multicolumn{1}{c}{$\mathrm{T}_{\mathrm{t}}$} & \multicolumn{1}{c}{$\mathrm{Y}_{\mathrm{t}+1}$} & $\mathrm{Y}_{\mathrm{t}}-\hat{\mathrm{Y}}_{\mathrm{t}} \mid \mathrm{Y}_{\mathrm{t}} \mathrm{x} 100$ \\
\hline 1 & 8.174 .897 & & & & \\
2 & 7.722 .611 & 7.722 .611 & -452.286 & & \\
3 & 8.198 .084 & 7.982 .342 & -158.926 & 7.270 .325 & 0,113 \\
4 & 8.359 .105 & 8.234 .536 & 10.460 & 7.823 .416 & 0,064 \\
5 & 8.328 .756 & 8.309 .278 & 36.945 & 8.244 .996 & 0,010 \\
6 & 8.594 .043 & 8.536 .415 & 115.306 & 8.346 .224 & 0,029 \\
7 & 8.345 .854 & 8.416 .981 & 18.590 & 8.651 .721 & 0,037 \\
8 & 8.475 .412 & 8.466 .147 & 31.188 & 8.435 .571 & 0,005 \\
9 & 8.289 .927 & 8.338 .158 & -34.395 & 8.497 .336 & 0,025 \\
10 & 8.503 .523 & 8.457 .071 & 28.770 & 8.303 .763 & 0,023 \\
11 & 8.123 .839 & 8.208 .019 & -85.696 & 8.485 .840 & 0,045 \\
12 & 8.512 .555 & 8.421 .810 & 37.696 & 8.122 .323 & 0,046 \\
13 & 8.424 .096 & 8.432 .330 & 26.499 & 8.459 .507 & 0,004 \\
14 & 8.729 .291 & 8.666 .398 & 112.020 & 8.458 .830 & 0,031 \\
15 & 8.616 .855 & 8.654 .425 & 60.933 & 8.778 .418 & 0,019 \\
16 & 9.136 .405 & 9.038 .495 & 194.069 & 8.715 .358 & 0,046 \\
17 & 9.600 .415 & 9.514 .875 & 310.385 & 9.232 .564 & 0,038 \\
18 & 10.110 .830 & 10.044 .423 & 400.683 & 9.825 .260 & 0,028 \\
19 & 9.391 .959 & 9.636 .858 & 67.675 & 10.445 .106 & 0,112 \\
20 & 10.232 .934 & 10.110 .059 & 234.757 & 9.704 .534 & 0,052 \\
21 & 10.344 .816 & 10.344 .816 & 234.757 & 10.344 .816 & 0,000 \\
\hline & & & & &
\end{tabular}




\begin{tabular}{rrrrrr}
\hline $\mathrm{T}$ & \multicolumn{1}{c}{$\mathrm{Y}_{\mathrm{t}}$} & \multicolumn{1}{c}{$\mathrm{L}_{\mathrm{t}}$} & \multicolumn{1}{c}{$\mathrm{T}_{\mathrm{t}}$} & \multicolumn{1}{c}{$\mathrm{Y}_{\mathrm{t}+1}$} & $\mathrm{Y}_{\mathrm{t}^{-}} \hat{\mathrm{Y}}_{\mathrm{t}} / \mathrm{Y}_{\mathrm{t}} \times 100$ \\
\hline 22 & 9.648 .104 & 9.864 .708 & -59.776 & 10.579 .573 & 0,097 \\
23 & 11.301 .422 & 10.953 .427 & 413.418 & 9.804 .932 & 0,132 \\
24 & 11.473 .261 & 11.448 .515 & 447.067 & 11.366 .845 & 0,009 \\
25 & 11.395 .395 & 11.511 .709 & 288.906 & 11.895 .582 & 0,044 \\
26 & 10.499 .588 & 10.802 .130 & -122.482 & 11.800 .615 & 0,124 \\
27 & 9.655 .654 & 9.893 .774 & -446.271 & 10.679 .648 & 0,106 \\
28 & 9.586 .911 & 9.554 .493 & -402.190 & 9.447 .503 & 0,015 \\
& & & & MAPE & 4,83 \\
\hline
\end{tabular}

\subsection{Peramalan Produksi Padi 5 Tahun ke Depan}

Peramalan untuk tahun periode ke 29 adalah sebagai berikut:

$$
\begin{aligned}
& \hat{\mathrm{Y}}_{29}=\mathrm{L}_{28}+(29-28) \mathrm{T}_{28} \\
& \hat{\mathrm{Y}}_{29}=9.554 .493+(1)(-402.190)=9.152 .303
\end{aligned}
$$

Hasil peramalan untuk 5 tahun ditampilkan pada Tabel 7 dimana hasil peramalan produksi beras secara time series di Provinsi Jawa Tengah menunjukkan adanya penurunan produksi. Penurunan tejadi karena nilai tren pada model akhir peramalan bernilai negatif. Penurunan produksi berdasarkan peramalan sebesar 402.190 ton setiap tahunnya. Meskipun mengalami penurunan produksi, tetapi masih dapat memenuhi kebutuhan konsumsi beras di Provinsi Jawa Tengah. Penurunan produksi berdampak pada cadangan beras Provinsi Jawa Tengah untuk suplai beras nasional.

Tabel 7 Peramalan Produksi Beras 5 Tahun Kedepan

\begin{tabular}{ccc}
\hline Periode & Tahun & Peramalan \\
\hline 1 & 2021 & 9.152 .303 \\
2 & 2022 & 8.750 .113 \\
3 & 2023 & 8.347 .923 \\
4 & 2024 & 7.945 .733 \\
5 & 2025 & 7.543 .543 \\
\hline
\end{tabular}

\section{KESIMPULAN}

Peramalan produksi padi di provinsi Jawa Tengah menggunakan metode double exponential smoothing atau metode Holts. Dengan nilai konstanta optimal $\alpha$ sebesar 0,767 dan $\beta$ sebesar 0,413 . Hasil dari peramalan produksi beras provinsi Jawa Tengah menunjukkan adanya penurunan produksi ke depannya, karena nilai tren produksi beras provinsi Jawa Tengah bernilai negatif. Penurunan produksi beras dalam 5 tahun ke depan antara 3,12 hingg 5,06\%. Rata-rata penurunan produksi beras dalam 5 tahun ke depan adalah sebesar $4,40 \%$ per tahunnya. Saran untuk penelitian selanjutnya, dapat dilakukan peramalan dengan metode kausal dengan mempertimbangkan pengaruh variabel-variabel lain yang mempengaruhi produksi beras pada umumnya. 


\section{DAFTAR PUSTAKA}

Aziz, Z. R. and Sopha, B. M., 2016, Peramalan Produksi Padi di Provinsi Daerah Istimewa Yogyakarta, Skripsi, Fakultas Teknik, Universitas Gadjah Mada, Yogyakarta.

Badan Pusat Statisitk, 2020, Provinsi Jawa Tengah Dalam Angka 2020, Semarang.

Bashir, A. and Yuliana, S., 2019, Identifying factors influencing rice production and consumption in Indonesia, Jurnal Ekonomi Pembangunan: Kajian Masalah Ekonomi dan Pembangunan, 19 (2), pp. 172-185. doi: 10.23917/jep.v19i2.5939.

Djafar, Sarita, M. I. and Pasrun, Y. P., 2017, Peramalan jumlah produksi padi di sulawesi tenggara menggunakan metode fuzzy time series, SEMANTIK, 3(2), pp. 113-120.

Hanke, J. E. and Wichern, D., 2014, Business Forecasting, Ed.9, London: Pearson Education Limited.

Kartikawati, I. and Asih, A. M. S., 2017, Analisis Peramalan Supply dan Demand Komoditas Beras 33 Provinsi di Indonesia, Skripsi, Fakultas Teknik, Universitas Gadjah Mada, Yogyakarta.

Montgomery, D. C., Jennings, C. L. and Kulahcy, M., 2008, Introduction to Time Series Analysis and Forecasting, New Jersey: John Willey \& Sons.

Nugroho, E. D. and Sitepu, R., 2017, Peramalan Jumlah Produksi Beras di Sumatera Utara Tahun 2019, Tugas Akhir. Departemen Matematika, Universitas Sumatera Utara, Medan.

Nurjayanti, E. D., Darsono. and Supardi, S., 2012, Dinamika dan Model Arima Penawaran Beras di Kabupaten Sukoharjo Sebelum dan Selama Pelaksanaan Otonomi Daerah (Periode Tahun 1994-2010), Jurnal Ilmu - ilmu Pertanian, 8(1), pp. 61-71.

Panuju, D. R., Mizuno, K. and Trisasongko, B. H., 2013, The dynamics of rice production in Indonesia 1961-2009, Journal of the Saudi Society of Agricultural Sciences, 12(1), pp. 27-37. doi: 10.1016/j.jssas.2012.05.002.

Stevenson, W. J., 2002, Operations Manajemen, Ed.7, New York: McGraw-Hill.

Subagyo, 2008, Forecasting Konsep dan Aplikasi, Yogyakarta: BPPE. 